Article

\title{
Cinnamaldehyde Ameliorates Cadmium-Inhibited Root Elongation in Tobacco Seedlings via Decreasing Endogenous Hydrogen Sulfide Production
}

\author{
Xie-Feng Ye ${ }^{1,+}$, Yanfeng Xue ${ }^{2,+}$, Tianxiao Ling ${ }^{1,+}$, Yong Wang ${ }^{3}$, Xiao-Na Yu ${ }^{1}$, Changxin Cheng ${ }^{4}$, \\ Guosheng Feng ${ }^{5}$, Liangbin $\mathrm{Hu}^{6}{ }^{6}$, Zhiqi Shi ${ }^{7,8, *}$ and Jian Chen ${ }^{7,8, *}$ \\ 1 Tobacco Science College/National Tobacco Cultivation and Physiology and Biochemistry Research \\ Centre/Key Laboratory for Tobacco Cultivation of Tobacco Industry, Henan Agricultural University, \\ Zhengzhou 450002, China; yexiefeng@163.com (X.-F.Y.); 18837103304@163.com (T.L.); \\ yuxiaona1129@163.com (X.-N.Y.) \\ 2 Nanjing Yangzi Modern Agriculture Investment and Development Co. Ltd., Nanjing 211899, China; \\ hnndxyf@163.com \\ 3 Chongqing Tobacco Corporation, Chongqing 400023, China; wangyong08326488@163.com \\ 4 Hongyun Honghe Tobacco Group Co. Ltd., Kunming 650231, China; ccxin1003@163.com \\ 5 Henan Tobacco Corporation Queshan Branch, Queshan 463200, China; fenggsheng@163.com \\ 6 Department of Food Science, Henan Institute of Science and Technology, Xinxiang 453003, China; \\ hulb973@163.com \\ 7 Institute of Food Quality and Safety, Jiangsu Academy of Agricultural Sciences, Nanjing 210014, China \\ 8 Key Lab of Food Quality and Safety of Jiangsu Province-State Key Laboratory Breeding Base, \\ Nanjing 210014, China \\ * Correspondence: shizhiqi@jaas.ac.cn (Z.S.); jacksonchen206@gmail.com (J.C.); Tel.: +86-25-8439-1863 (J.C.) \\ $\dagger$ These authors contribute equally to this work.
}

Academic Editor: Derek J. McPhee

Received: 31 October 2016; Accepted: 22 December 2016; Published: 24 December 2016

\begin{abstract}
Cinnamaldehyde (CA) is natural plant-derived compound that has been highly appreciated for its medicinal properties. However, little information is known about the regulation of plant intrinsic physiology by CA. To address these gaps, physiological, histochemical, and biochemical approaches were applied to investigate CA-facilitated cadmium (Cd) tolerance in the roots of tobacco (Nicotiana tabacum) seedlings. Treatment with $\mathrm{CdCl}_{2}$ at $20 \mu \mathrm{M}$ for $72 \mathrm{~h}$ resulted in the significant decrease in root elongation by $40.39 \%$ as compared to control. CA alleviated Cd-inhibited root elongation in dose- and time-dependent manners. The addition of CA at $20 \mu \mathrm{M}$ induced significant increase in root elongation by $42.58 \%$ as compared to $\mathrm{Cd}$ treatment alone. CA abolished Cd-induced ROS (reactive oxygen species) accumulation, lipid peroxidation, loss of membrane integrity, cell death, and free $\mathrm{Cd}^{2+}$ accumulation in roots. CA blocked the Cd-induced increase in the endogenous $\mathrm{H}_{2} \mathrm{~S}$ level through the down-regulation of D-cysteine desulfhydrase (DCD) expression. $\mathrm{H}_{2} \mathrm{~S}$ scavenger hypotaurine (HT) or potent $\mathrm{H}_{2} \mathrm{~S}$-biosynthetic inhibitor DL-propargylglicine (PAG) were able mimic the action of $\mathrm{CA}$ on the blockade of $\mathrm{Cd}$-induced $\mathrm{H}_{2} \mathrm{~S}$ accumulation, cell death, and growth inhibition. Enhancement of the endogenous $\mathrm{H}_{2} \mathrm{~S}$ level with $\mathrm{NaHS}\left(\mathrm{H}_{2} \mathrm{~S}\right.$ donor $)$ abrogated all the beneficial capabilities of CA, HT, and PAG. Collectively, these results suggest that CA has great potential to confer plant tolerance against $\mathrm{Cd}$ stress, which is closely associated with its capability to inhibit $\mathrm{Cd}$-induced $\mathrm{H}_{2} \mathrm{~S}$ production. This study not only provides evidences for the regulation of plant physiology by CA but also sheds new light on the cross-talk between $\mathrm{CA}$ and $\mathrm{H}_{2} \mathrm{~S}$ in physiological modulations.
\end{abstract}

Keywords: cinnamaldehyde; hydrogen sulfide; reactive oxygen species; cell death; cadmium; tobacco 


\section{Introduction}

Cinnamaldehyde (CA) is an important component of essential oil obtained from cinnamon trees and other Cinnamomum species [1,2]. CA is a bioactive compound that has been highly appreciated for its medicinal properties, such as anti-oxidative and anti-inflammatory properties [3,4], anti-microbial activity [5], anti-viral activity [6], and anti-cancer activity [7]. The clinical relevance of CA has been closely linked to the regulation of immune pathways in mammalian cells, which can be mediated by several important signaling molecules, such as $\mathrm{Ca}^{2+}$ and nitric oxide (NO) $[8,9]$. CA also shows great potential to maintain food quality due to its anti-microbial activity [10]. The bioactivity of CA on both mammals and microorganisms has been identified extensively, but little information is known about the regulation of plant-resistant physiology by CA.

Plant growth is impacted by multiple environmental stresses, including heavy metals. Cadmium (Cd) pollution is becoming a global problem because of the natural and anthropogenic release of $\mathrm{Cd}$ into the environment [11]. Ionic cadmium $\left(\mathrm{Cd}^{2+}\right)$ is the ubiquitous form of $\mathrm{Cd}$ existing in the environment. $\mathrm{Cd}^{2+}$ can be easily absorbed and accumulated in plants, which further shows adverse effects on plant growth and poses a risk to human health through the food chain [12]. Cd stress frequently induces the accumulation of ROS (reactive oxygen species), leading to the occurrence of oxidative stress, cell death, and growth inhibition in plants [13].

Hydrogen sulfide $\left(\mathrm{H}_{2} \mathrm{~S}\right)$ is a toxic gaseous molecule in the environment. However, $\mathrm{H}_{2} \mathrm{~S}$ is also an endogenously-generated regulator of a variety of biological processes in mammals and plants [14,15]. $\mathrm{H}_{2} \mathrm{~S}$ and CA share many downstream regulatory networks that involve ROS, $\mathrm{NO}$, and $\mathrm{Ca}^{2+}$ in mammalian cells $[8,16,17]$, but the interaction between $\mathrm{H}_{2} \mathrm{~S}$ and CA during physiological modulation is little known. In mammals, pyridoxal $5^{\prime}$-phosphate (PLP)-dependent family proteins, cystathionine- $\gamma$-lyase (CSE) and cystathionine- $\beta$-synthase (CBS), are two key enzyme for the endogenous production of $\mathrm{H}_{2} \mathrm{~S}$ [18]. In plant cells, $\mathrm{H}_{2} \mathrm{~S}$ can be endogenously produced from cysteine desulfuration catalyzed by L-cysteine desulfhydrase (LCD) and D-cysteine desulfhydrase (DCD), also belonging to PLP-dependent protein family $[19,20] . \mathrm{H}_{2} \mathrm{~S}$ has been considered as an important regulator for the modulation of plant physiology under various environmental stimuli, including heavy metal stress [21]. It has been documented that $\mathrm{H}_{2} \mathrm{~S}$ is involved in the regulation of plant responses to $\mathrm{Cd}$ stress [22-28]. The interaction between $\mathrm{H}_{2} \mathrm{~S}$ and other signaling molecules (e.g., $\mathrm{NO}$ and $\mathrm{Ca}^{2+}$ ) to modulate ROS homeostasis has been identified in various plant species under heavy metal stress $[24,26,29]$. Thus, it can be speculated that the interaction between $\mathrm{CA}$ and $\mathrm{H}_{2} \mathrm{~S}$ probably exists during plant physiological regulation under environmental stimuli.

In this work, we first studied the alleviating effect of $\mathrm{CA}$ on $\mathrm{CdCl}_{2}$-induced growth inhibition, oxidative injury, and free $\mathrm{Cd}^{2+}$ accumulation in the root of tobacco (Nicotiana tabacum) seedlings. To further investigate the hypothesis that $\mathrm{H}_{2} \mathrm{~S}$ may be involved in CA-mediated alleviation of Cd-induced phytotoxicity, we detected the effect of $\mathrm{CA}$ on endogenous $\mathrm{H}_{2} \mathrm{~S}$ distribution and the expression level of $L C D$ and $D C D$ in $\mathrm{CdCl}_{2}$-treated roots. Then plant roots were treated with $C A$, $\mathrm{CdCl}_{2}$, the $\mathrm{H}_{2} \mathrm{~S}$ donor sodium hydrosulfide (NaHS), the $\mathrm{H}_{2} \mathrm{~S}$ scavenger hypotaurine (HT), and potent $\mathrm{H}_{2} \mathrm{~S}$-biosynthetic inhibitor DL-propargylglycine (PAG), alone or in various combinations, for the determination of endogenous $\mathrm{H}_{2} \mathrm{~S}$, root elongation, and cell death. Finally, the possible mechanisms for the interaction among these parameters are discussed.

\section{Results}

\subsection{CA Significantly Mitigated Cd-Induced Inhibition of Root Elongation in Tobacco Seedlings}

Treatment with $\mathrm{CdCl}_{2}$ at $20 \mu \mathrm{M}$ for $72 \mathrm{~h}$ resulted in the significant decrease in root elongation by $40.39 \%$ as compared to control (Figure $1 \mathrm{~A})$. CA with different concentrations $(0-40 \mu \mathrm{M})$ was added to the treatment solution to investigate the effect of $\mathrm{CA}$ on the modulation of root elongation under $\mathrm{Cd}$ stress. As compared to $\mathrm{Cd}$ treatment alone, the addition of $\mathrm{CA}$ at $5,10,20$, and $40 \mu \mathrm{M}$, induced significant increase in root elongation by $22.58 \%, 29.03 \%, 42.58 \%$, and $14.19 \%$, respectively (Figure 1A). 
CA at $80 \mu \mathrm{M}$ failed to stimulate root elongation under Cd exposure (Figure 1A). CA at $20 \mu \mathrm{M}$ showed the greatest effect on the alleviation of Cd-induced inhibition of root elongation. Therefore, $20 \mu \mathrm{M}$ of CA was used for further estimation of physiological responses. In a time-course experiment up to $72 \mathrm{~h}$, root elongation began to significantly increase after treatment with $\mathrm{CA}+\mathrm{Cd}$ for $24 \mathrm{~h}$ as compared to Cd treatment alone. CA at $20 \mu \mathrm{M}$ showed continuous alleviating effect on Cd-induced inhibition of root elongation after treatment for 24-72 h (Figure 1B). In addition, the addition of CA significantly enhanced root fresh weight under Cd stress (Figure 1C). These results suggested that CA recovered root growth of tobacco seedlings from Cd stress.
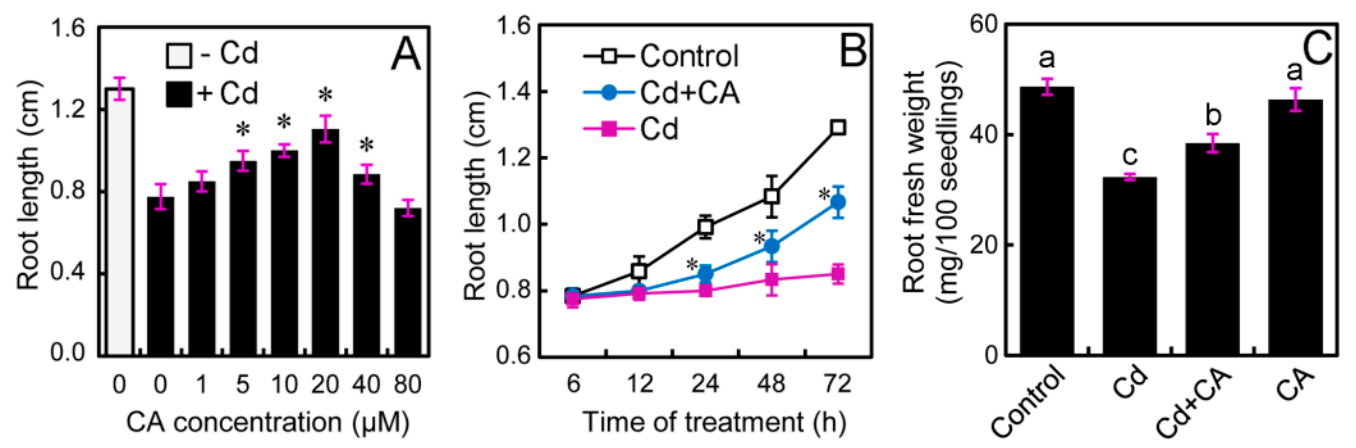

Figure 1. The effect of CA on root growth of tobacco seedlings under Cd stress. (A) In the presence of $\mathrm{CdCl}_{2}$ at $20 \mu \mathrm{M}$, the roots of seedlings were treated with CA at different concentrations $(0-80 \mu \mathrm{M})$ for $72 \mathrm{~h}$. Then the root length was measured; (B) the roots of seedlings were exposed to $20 \mu \mathrm{M}$ of $\mathrm{CdCl}_{2}$ and $20 \mu \mathrm{M}$ of CA simultaneously for $6,12,24,48$, and $72 \mathrm{~h}$, respectively, for the measurement of root length; (C) the roots of seedlings were treated with water, $20 \mu \mathrm{M}$ of $\mathrm{CdCl}_{2}, 20 \mu \mathrm{M}$ of CA, alone or their combinations for $72 \mathrm{~h}$. Then the roots were harvested for the quantification of fresh weight. The asterisk $\left(^{*}\right)$ in $(\mathbf{A}, \mathbf{B})$ indicated that the mean value of six replicates was significantly different between $\mathrm{Cd}+\mathrm{CA}$ treatment and Cd treatment alone $(p<0.05$, ANOVA). Different letters in $(C)$ indicated that the mean values of three replicates are significantly different between the treatments $(p<0.05$, ANOVA, LSD).

\subsection{CA Inhibited Cd-Induced ROS Over-Generation in the Roots of Tobacco Seedlings}

Fluorescent probe DCFH-DA $\left(2^{\prime}, 7^{\prime}\right.$-dichlorofluorescein diacetate), reacting specifically with ROS to form DCF ( $2^{\prime}, 7^{\prime}$-dichlorofluorescein) emitting green fluorescence, was used to detect total ROS in situ in roots. Cd-treated roots showed stronger DCF fluorescence than that of control (Figure 2A). However, $\mathrm{Cd}+\mathrm{CA}$ treatment weakened DCF fluorescence in roots as compared to $\mathrm{Cd}$ treatment alone (Figure 2A). The quantification of DCF fluorescent density suggested that the relative total ROS content in Cd-treated root significantly increased as compared to the control (Figure 2B). Nevertheless, $\mathrm{Cd}+\mathrm{CA}$ treatment led to remarkable decrease in the relative total ROS content in root by $63.09 \%$ as compared to $\mathrm{Cd}$ treatment alone (Figure 2B). CA treatment alone did not significantly change total ROS content in roots under normal growth conditions (Figure 2B).

Hydrogen peroxide $\left(\mathrm{H}_{2} \mathrm{O}_{2}\right)$ and superoxide radical $\left(\mathrm{O}_{2}{ }^{--}\right)$are two typical ROS induced by heavy metal stress in plants [30]. Endogenous $\mathrm{H}_{2} \mathrm{O}_{2}$ in roots was detected in situ with the specific fluorescent probe HPF ( $3^{\prime}-\left(p\right.$-hydroxyphenyl) fluorescein), presenting green fluorescence. As expected, $\mathrm{H}_{2} \mathrm{O}_{2}$ content in roots increased remarkably by $215.40 \%$ under $\mathrm{Cd}$ exposure, which was decreased to the control level by the addition of CA (Figure 2C,D). Endogenous $\mathrm{O}_{2}{ }^{\bullet-}$ in roots was selectively detected in situ with the specific fluorescent probe DHE (dihydroethidium), presenting red fluorescence (Figure 2E). $\mathrm{Cd}$ treatment led to a significant increase in $\mathrm{O}_{2}{ }^{--}$content in roots by $198.07 \%$ as compared to control (Figure 2F). However, treatment with $\mathrm{Cd}+\mathrm{CA}$ significantly decreased $\mathrm{O}_{2}{ }^{--}$content by $55.91 \%$ in roots as compared to $\mathrm{Cd}$ treatment alone (Figure 2F). Neither $\mathrm{H}_{2} \mathrm{O}_{2}$ nor $\mathrm{O}_{2}{ }^{-{ }^{-}}$in roots was affected by CA treatment alone (Figure 2D,F). These results suggested that $\mathrm{CA}$ was able to inhibit ROS accumulation in the roots of tobacco seedlings under Cd stress. 

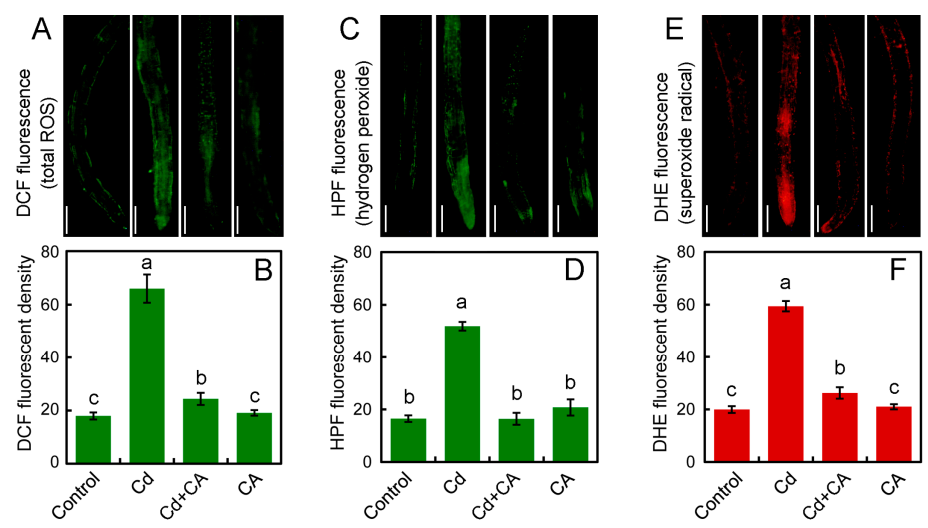

Figure 2. The effect of CA on ROS accumulation in the roots of tobacco seedlings under Cd stress. The roots of seedlings were treated with distilled water (control), $\mathrm{CdCl}_{2}(20 \mu \mathrm{M}), \mathrm{CdCl}_{2}(20 \mu \mathrm{M})+\mathrm{CA}$ $(20 \mu \mathrm{M})$, and CA $(20 \mu \mathrm{M})$ for $72 \mathrm{~h}$. (A) The roots were loaded with DCFH-DA for the observation of total ROS fluorescence with fluorescent microscope; (B) The DCF fluorescent density was quantified to indicate the relative total ROS level in roots; $(\mathbf{C})$ the roots were loaded with HPF for the observation of endogenous $\mathrm{H}_{2} \mathrm{O}_{2}$ with fluorescent microscope; (D) the HPF fluorescent density was quantified to indicate the relative $\mathrm{H}_{2} \mathrm{O}_{2}$ level in roots; (E) the roots were loaded with DHE for the observation of endogenous $\mathrm{O}_{2}{ }^{\bullet-}$ with fluorescent microscope; (F) the DHE fluorescent density was quantified to indicate the relative $\mathrm{O}_{2}{ }^{\bullet-}$ level in roots. $\mathrm{Bar}=0.5 \mathrm{~mm}$. Different letters in (B), (D), and (F) indicate that the mean values of three replicates are significantly different between the treatments $(p<0.05$, ANOVA, LSD).

\subsection{CA Ameliorated Cd-Induced Oxidative Injury in the Roots of Tobacco Seedlings}

Lipid peroxidation of the cell membrane is one of the typical consequences of oxidative injury in plants in response to abiotic stress [31]. In the present study, peroxidation of membrane lipids and the loss of plasma membrane integrity were detected in vivo by using histochemical staining with Shiff's reagent and Evans blue, respectively. Cd-treatment alone led to extensive staining in roots, while the roots treated with CA $+\mathrm{Cd}$ and control had only light staining (Figure 3A,B). TBARS (thiobarbituric acid reactive substances) content is a typical indicator of lipid peroxidation. $\mathrm{Cd}$ treatment induced significant increase in TRARS level by $112.07 \%$ in roots as compared to control (Figure 3C). However, $\mathrm{Cd}+\mathrm{CA}$ treatment led to the significant decrease in TBARS content by $38.26 \%$ in roots as compared to the control (Figure $3 \mathrm{C}$ ). These results suggested that $\mathrm{CA}$ remarkably attenuated $\mathrm{Cd}$-induced oxidative injury in the roots of tobacco seedlings.
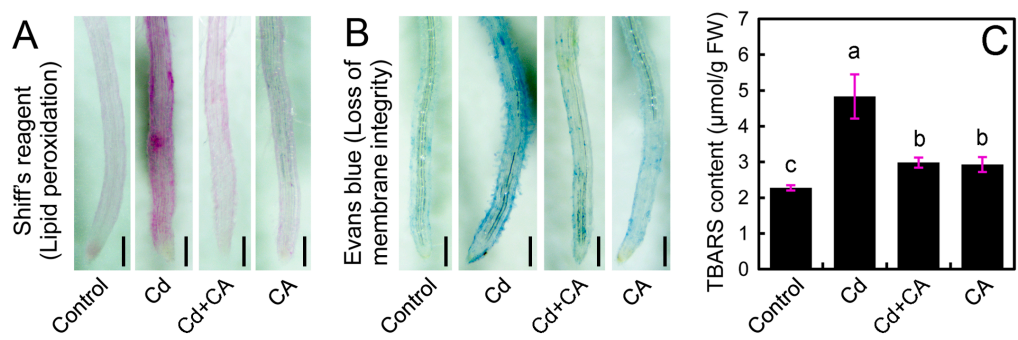

Figure 3. The effect of CA on lipid peroxidation, loss of membrane integrity, and TBARS content in the roots of tobacco seedlings under $\mathrm{Cd}$ stress. The roots of seedlings were treated with distilled water (control), $\mathrm{CdCl}_{2}(20 \mu \mathrm{M}), \mathrm{CdCl}_{2}(20 \mu \mathrm{M})+\mathrm{CA}(20 \mu \mathrm{M})$, and CA $(20 \mu \mathrm{M})$ for $72 \mathrm{~h}$. After treatment, the roots were stained with Shiff's reagent $(\mathbf{A})$ and Evans blue (B), respectively, followed by photographing with a stereoscopic microscope. Bar $=0.5 \mathrm{~mm}$; and $(\mathbf{C})$ the roots after treatment were harvested for the determination of TBARS content. Different letters indicate that the mean values of three replicates are significantly different between the treatments $(p<0.05$, ANOVA, LSD). 


\section{4. $\mathrm{CA}$ Decreased Free $C d^{2+}$ Accumulation in the Roots of Tobacco Seedlings}

Leadmium $^{\text {TM }}$ Green AM (Invitrogen Molecular Probes, Inc., Eugene, OR, USA) with the capability of reacting with free $\mathrm{Cd}^{2+}$ to emit green fluorescence was used to selectively detect free $\mathrm{Cd}^{2+}$ in roots. In the present study, we did not detect any fluorescent signal in the roots of control and CA treatment alone. The roots treated with $\mathrm{Cd}$ alone showed much stronger fluorescence than that of $\mathrm{Cd}+\mathrm{CA}$ treatment (Figure $4 \mathrm{~A}$ ). The fluorescent density of Leadmium Green significantly decreased by $63.56 \%$ in roots under $\mathrm{Cd}+\mathrm{CA}$ treatment as compared to $\mathrm{Cd}$ treatment alone (Figure $4 \mathrm{~B})$. These results indicated that the addition of CA significantly prohibited free $\mathrm{Cd}^{2+}$ accumulation in Cd-treated roots.
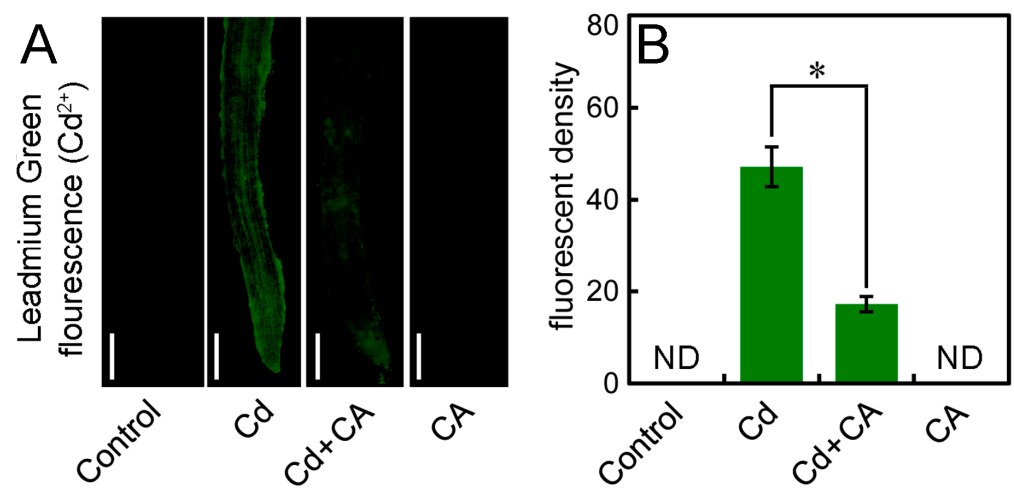

Figure 4. The effect of $\mathrm{CA}$ on free $\mathrm{Cd}^{2+}$ in the roots of tobacco seedlings under Cd stress. The roots of seedlings were treated with distilled water (control), $\mathrm{CdCl}_{2}(20 \mu \mathrm{M}), \mathrm{CdCl}_{2}(20 \mu \mathrm{M})+\mathrm{CA}(20 \mu \mathrm{M})$, and CA $(20 \mu \mathrm{M})$ for $72 \mathrm{~h}$. (A) The roots were loaded with Leadmium ${ }^{\mathrm{TM}}$ Green AM and photographed with a fluorescent microscope. Bar $=0.5 \mathrm{~mm}$; (B) The Leadmium Green fluorescent density was quantified to indicate the relative $\mathrm{Cd}^{2+}$ level in roots. The asterisk $\left(^{*}\right)$ indicates that the mean value of three replicates was significantly different between $\mathrm{Cd}+\mathrm{CA}$ treatment and $\mathrm{Cd}$ treatment alone $(p<0.05$, ANOVA).

\subsection{CA Remarkably Repressed Cd-Induced Production of Endogenou $\mathrm{H}_{2} \mathrm{~S}$ in the Roots of Tobacco Seedlings}

Specific molecular probe WSP-1 (Washington State Probe 1) was applied to selectively detect endogenous $\mathrm{H}_{2} \mathrm{~S}$ in roots. The endogenous $\mathrm{H}_{2} \mathrm{~S}$ level in roots significantly increased by $270.16 \%$ in response to $\mathrm{Cd}$ stress, which was decreased to the control level by the addition of $\mathrm{CA}$ (Figure 5). The addition of $\mathrm{NaHS}\left(\mathrm{H}_{2} \mathrm{~S}\right.$ donor) was able to enhance the endogenous $\mathrm{H}_{2} \mathrm{~S}$ content in roots treated with $\mathrm{Cd}+\mathrm{CA}$ (Figure 5). PAG $\left(\mathrm{H}_{2} \mathrm{~S}\right.$-biosynthetic inhibitor) or $\mathrm{HT}\left(\mathrm{H}_{2} \mathrm{~S}\right.$ scavenger) showed similar effects on the endogenous $\mathrm{H}_{2} \mathrm{~S}$ content in Cd-treated roots as compared to CA. The application of PAG or HT significantly decreased endogenous $\mathrm{H}_{2} \mathrm{~S}$ level in the Cd-treated roots, which could be reversed by the addition of NaHS, as well (Figure 5).

To understand how $\mathrm{Cd}$ and $\mathrm{CA}$ regulate the production of endogenous $\mathrm{H}_{2} \mathrm{~S}$, the expression level of $L C D$ and $D C D$ in roots upon different treatments was analyzed by using Real-time RT-PCR (reverse transcription-polymerase chain reaction). The expression level of $D C D$ significantly increased by $274.61 \%$ in Cd-treated roots compared to control. Treatment with $\mathrm{Cd}+\mathrm{CA}$ resulted in the dramatic decrease in $D C D$ expression level by $60.84 \%$ as compared to $C d$ treatment alone (Figure $6 \mathrm{~A}$ ). However, $\mathrm{Cd}$ treatment alone led to a slight decrease in the expression level of $L C D$ in roots as compared to control or $\mathrm{Cd}+\mathrm{CA}$ treatment (Figure 6B). Treatment with CA alone induced a slight increase in the expression level of $D C D$ and $L C D$ (Figure 6). 


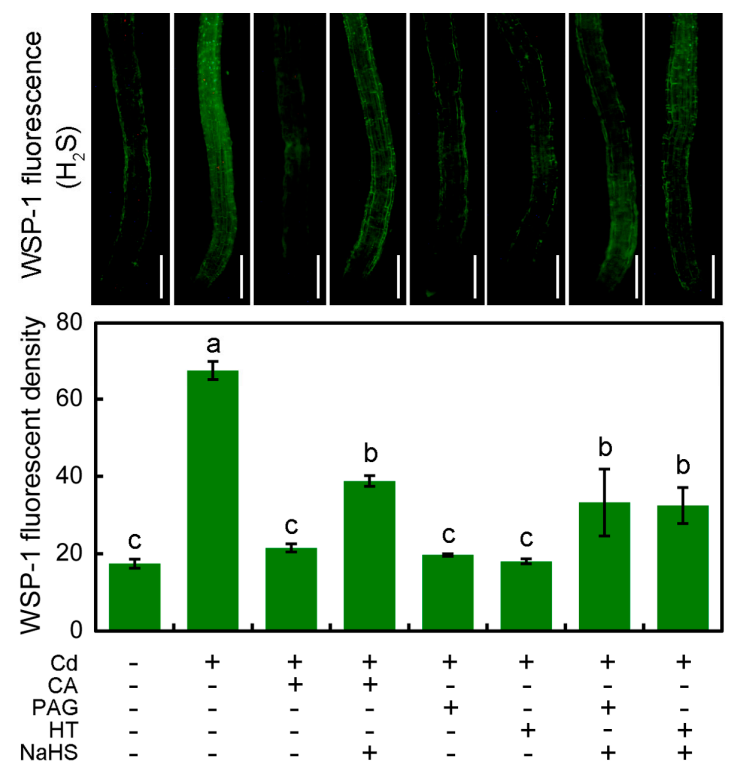

Figure 5. The effect of $\mathrm{CA}$ on endogenous $\mathrm{H}_{2} \mathrm{~S}$ content in the roots of tobacco seedlings under $\mathrm{Cd}$ stress. The roots of seedlings were treated with distilled water (control), $\mathrm{CdCl}_{2}(20 \mu \mathrm{M}), \mathrm{CA}(20 \mu \mathrm{M}), \mathrm{NaHS}$ $(20 \mu \mathrm{M})$, PAG $(2 \mu \mathrm{M})$, HT $(20 \mu \mathrm{M})$, alone or their combinations for $72 \mathrm{~h}$. Then the roots were loaded with WSP-1 for the observation of green fluorescence and the quantification of fluorescent density. Bar $=0.5 \mathrm{~mm}$. Different letters indicated that the mean values of six replicates were significantly different between the treatments $(p<0.05$, ANOVA, LSD).
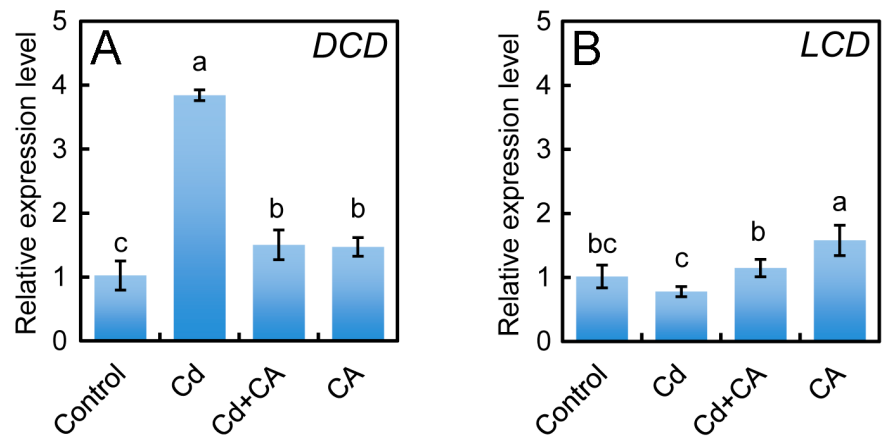

Figure 6. The effect of CA on the expression of $D C D$ and $L C D$ in the roots of tobacco seedlings under $\mathrm{Cd}$ stress. The roots of seedlings were treated with distilled water (control), $\mathrm{CdCl}_{2}(20 \mu \mathrm{M}), \mathrm{CdCl}_{2}$ $(20 \mu \mathrm{M})+\mathrm{CA}(20 \mu \mathrm{M})$, and CA $(20 \mu \mathrm{M})$ for $72 \mathrm{~h}$. Then the roots were harvested for RNA extraction to analyze the expression level of $D C D(\mathbf{A})$ and $L C D(\mathbf{B})$. Different letters indicated that the mean values of three replicates were significantly different between the treatments $(p<0.05$, ANOVA, LSD).

\subsection{CA Alleviated Cd-Inhibited Root Elongation by Modulating Endogenous $\mathrm{H}_{2} \mathrm{~S}$ in Tobacco Seedlings}

CA significantly induced the increase in root elongation upon $\mathrm{Cd}$ stress, which was diminished by the addition of $\mathrm{H}_{2} \mathrm{~S}$ donor NaHS (Figure 7). Similar to $\mathrm{CA}$, treatment with $\mathrm{Cd}+\mathrm{PAG}$ or $\mathrm{Cd}+\mathrm{HT}$ induced significant increase in root elongation as compared to $\mathrm{Cd}$ treatment alone (Figure 7). The addition of NaHS diminished the promoting effect of PAG or HT on root elongation under Cd stress, as well (Figure 7). These results suggested that endogenous $\mathrm{H}_{2} \mathrm{~S}$ played negative role in the regulation of root elongation under $\mathrm{Cd}$ stress, and CA was able to alleviate $\mathrm{Cd}$-inhibited root growth by decreasing the endogenous $\mathrm{H}_{2} \mathrm{~S}$ in tobacco seedlings. 


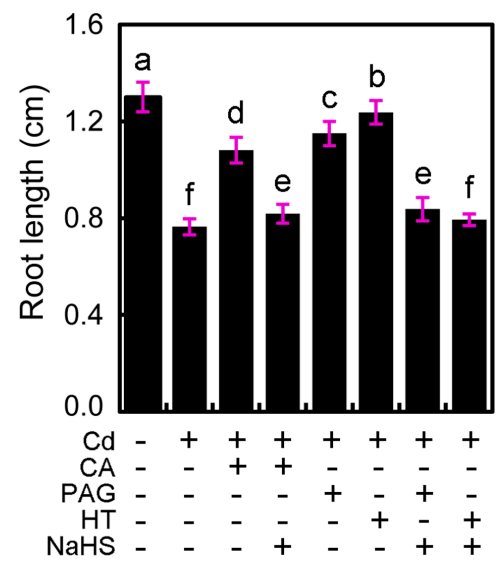

Figure 7. The effect of CA, NaHS, PAG, and HT on root elongation in tobacco seedlings under Cd stress. The roots of seedlings were treated with distilled water (control), $\mathrm{CdCl}_{2}(20 \mu \mathrm{M}), \mathrm{CA}(20 \mu \mathrm{M})$, NaHS $(20 \mu \mathrm{M})$, PAG $(2 \mu \mathrm{M})$, HT $(20 \mu \mathrm{M})$, alone or their combinations for $72 \mathrm{~h}$, for the measurement of root length. Different letters indicated that the mean values of five replicates were significantly different between the treatments ( $p<0.05$, ANOVA, LSD).

\subsection{CA Decreased Cd-Inhibited Cell Death by Modulating Endogenous $\mathrm{H}_{2} \mathrm{~S}$ in the Root of Tobacco Seedlings}

PI (propidium iodide) staining was performed to indicate cell death in the roots of tobacco seedlings. Cd treatment alone resulted in significant increase in PI fluorescent density by $216.95 \%$ as compared to control, suggesting that $\mathrm{Cd}$ stress induced severe cell death in roots (Figure 8). Treatment with $\mathrm{Cd}+\mathrm{CA}$ resulted in the significant decrease in PI fluorescent density by $50.41 \%$ as compared to $\mathrm{Cd}$ treatment alone. Similarly, the addition of PAG or HT was able to remarkably decrease PI fluorescent density in Cd-treated roots (Figure 8). However, the addition of NaHS diminished the effect of CA, PAG, or HT on PI fluorescent density in Cd-treated roots (Figure 8). These results suggested that endogenous $\mathrm{H}_{2} \mathrm{~S}$ played positive role in triggering cell death in $\mathrm{Cd}$-treated root, and CA was able to decrease $\mathrm{Cd}$-induced cell death by decreasing the endogenous $\mathrm{H}_{2} \mathrm{~S}$ in tobacco seedlings.
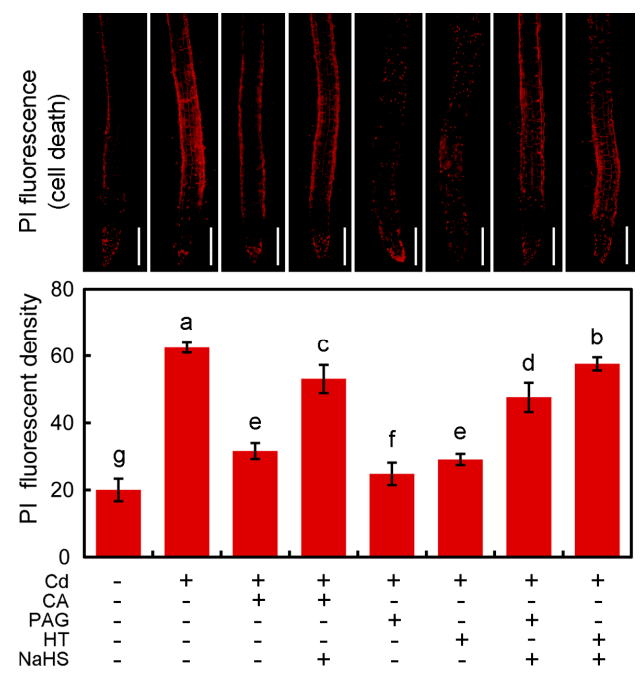

Figure 8. The effect of CA, NaHS, PAG, and HT on cell death in the root of tobacco seedlings under $\mathrm{Cd}$ stress. The roots of seedlings were treated with distilled water (control), $\mathrm{CdCl}_{2}(20 \mu \mathrm{M}), \mathrm{CA}$ $(20 \mu \mathrm{M})$, NaHS $(20 \mu \mathrm{M})$, PAG $(2 \mu \mathrm{M})$, HT $(20 \mu \mathrm{M})$, alone or their combinations for $72 \mathrm{~h}$. Then the roots were loaded with PI the microscopic observation of red fluorescence and the quantification of fluorescent density. Bar $=0.5 \mathrm{~mm}$. Different letters indicated that the mean values of three replicates were significantly different between the treatments ( $p<0.05$, ANOVA, LSD). 


\subsection{Hierarchical Cluster Analysis of the Interaction of $\mathrm{CA}$ and $\mathrm{H}_{2} \mathrm{~S}$ in Roots Exposed to Cd}

Based on the obtained data of RL (root length), endogenous $\mathrm{H}_{2} \mathrm{~S}$ content (indicated by WSP-1 fluorescent density), and cell death (indicated by PI fluorescent density) in roots upon different treatments (Figures 5, 7 and 8), hierarchical clustering was performed to analyze the relationship among biochemical parameters or different treatments (Figure 9). For the biochemical parameters, $\mathrm{H}_{2} \mathrm{~S}$ and PI were in the same group (Figure 9, A), indicating that they were negatively related to root elongation upon different treatments. For different treatments, $\mathrm{Cd}+\mathrm{CA}, \mathrm{Cd}+\mathrm{PAG}$, and $\mathrm{Cd}+\mathrm{HT}$ were in the same group (Figure 9, B). CA, PAG, and HT showed similar effects on the decrease in $\mathrm{Cd}$-induced $\mathrm{H}_{2} \mathrm{~S}$ in roots, which was associated with the recovery of root from Cd-induced growth inhibition and cell death (Figure 9, B). The addition of NaHS was able to block the effect of PAG, HT, or CA on all the parameters in Cd-roots (Figure 9, C), showing similar patterns with Cd-treatment alone (Figure 9, D).

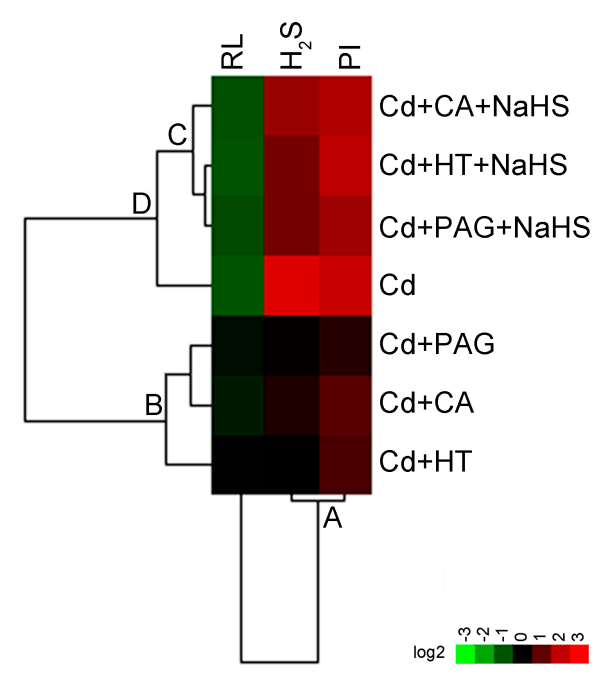

Figure 9. Hierarchical cluster analysis of interaction between $\mathrm{CA}$ and $\mathrm{H}_{2} \mathrm{~S}$ on physiological responses of tobacco seedling roots under Cd stress. The relative data of $\mathrm{RL}$ (root length), $\mathrm{H}_{2} \mathrm{~S}$ content (indicated by WSP-1 fluorescent density), and cell death (indicated by PI fluorescent density) in roots with different treatment, were selected for cluster analysis. All of the data were presented as relative fold changes with respect to control. The cluster color bar was shown as a $\log _{2}$ fold change. Red indicates an increase while green indicates a decrease.

\section{Discussion}

The medicinal properties of CA have been reported extensively [2], but the role of CA in the regulation of plant physiology remains elusive. It has been demonstrated that CA is capable of protecting mammalian cells against stress conditions [32,33]. In the present study, four lines of evidence indicate that CA is able to protect tobacco seedlings from Cd stress by decreasing the endogenous $\mathrm{H}_{2} \mathrm{~S}$ in roots. Firstly, CA attenuated $\mathrm{Cd}$-induced growth inhibition, oxidative injury, and cell death in roots. Secondly, $\mathrm{Cd}$ stimulated $\mathrm{DCD}$-dependent $\mathrm{H}_{2} \mathrm{~S}$ generation in roots, which was repressed by $\mathrm{CA}$. Thirdly, the application of the $\mathrm{H}_{2} \mathrm{~S}$-biosynthetic inhibitor (PAG) of the $\mathrm{H}_{2} \mathrm{~S}$ scavenger (HT) showed similar action to CA. PAG or HT blocked the increase in the endogenous $\mathrm{H}_{2} \mathrm{~S}$ level in Cd-treated roots, coinciding with the recovery of root growth and the decrease in cell death under Cd stress. Fourthly, the abilities of CA, HT, or PAG to alleviate Cd-induced phytotoxicity were greatly reduced by enhancing the endogenous $\mathrm{H}_{2} \mathrm{~S}$ with NaHS.

Growth inhibition is a typical symptom in plants in response to organic and inorganic contaminants [34,35]. Measurement of root elongation has been recommended as a reliable method for phytotoxicity testing of hazardous substances, including heavy metals [35,36]. Our current results 
suggested that CA at a proper dose significantly attenuated Cd-induced inhibition of root elongation, suggesting that CA protected plants from Cd toxicity. However, CA at high dose $(40 \mu \mathrm{M})$ showed decreased ability of inducing plant tolerance against $\mathrm{Cd}$ as compared to $20 \mu \mathrm{M}$ of $\mathrm{CA}$. CA at $80 \mu \mathrm{M}$ even failed to restore root elongation under $\mathrm{Cd}$ exposure. It has been demonstrated that CA shows adverse effects on plant growth [37]. We also observed that treatment with CA at high dose alone was able to inhibit root elongation (data not shown), which may compromise its protective effect against Cd stress. The antioxidative and antiperoxidative properties of CA are important for its capacity protecting mammalian cells from stress conditions [38]. Here we found that CA combated Cd toxicity in plants through the similar mechanism. Cd-induced phytotoxicity is largely attributed to ROS accumulation in plant cells $[39,40]$. The over-generated ROS always triggers oxidative injury and cell death in plants [41]. ROS frequently attack membrane lipids to induce lipid peroxidation of the plasma membrane indicated by TBARS [42,43]. In the present study, CA attenuated Cd-induced lipid peroxidation and plasma membrane damage, which may have resulted from the repression of ROS accumulation (including $\mathrm{H}_{2} \mathrm{O}_{2}$ and $\mathrm{O}_{2}{ }^{\bullet-}$ ) in the roots of tobacco seedlings upon $\mathrm{Cd}$ exposure. CA has the ability to scavenge ROS directly in vitro [38], which may partially contribute to the alleviation of $\mathrm{Cd}$-induced cytotoxicity in the roots of tobacco seedlings. NADPH (nicotinamide adenine dinucleotide phosphate) oxidase located in the plasma membrane has been suggested to be a major source for ROS generation in plants under environmental stimuli [44]. Cd-induced tobacco cell death is ascribed to NADPH oxidase-dependent ROS production $[39,45]$. In mammalian cells, the cardioprotective effect of CA has been linked to its ability to decrease NADPH activity and ROS production [46]. In Cd-treated tobacco roots, whether CA inhibits ROS accumulation through the similar mechanism needs to be studied further. Moreover, the ability of CA to decrease ROS in vivo has been closely related to the regulation of various intracellular signaling in mammalian cells [46-48]. Notably, the inhibition of endogenous NO generation is critical for the anti-inflammatory and anti-carcinogenic activity of CA $[4,49,50]$. The interaction between NO and ROS is important for triggering cell death in both mammals and plants [51,52]. It has been reported that $\mathrm{NO}$-dependent $\mathrm{H}_{2} \mathrm{O}_{2}$ production is required for $\mathrm{Cd}$-induced cell death in Arabidopsis suspension cells [53]. Therefore, whether CA prevents Cd-induced cell death by inhibiting $\mathrm{NO} / \mathrm{H}_{2} \mathrm{O}_{2}$ interaction in tobacco seedlings remains to be investigated further.

The knowledge about $\mathrm{H}_{2} \mathrm{~S}$ in plants are relatively limited as compared to those in mammals [15]. Recently, $\mathrm{H}_{2} \mathrm{~S}$ has been drawing great attention because of its emerging role in the regulation of plant physiology [21]. The increase in endogenous $\mathrm{H}_{2} \mathrm{~S}$ level has been observed in various plant species upon $\mathrm{Cd}$ exposure, but the physiological role of the suppression of $\mathrm{Cd}$-induced $\mathrm{H}_{2} \mathrm{~S}$ was rarely concerned [24-28]. In the present study, Cd stress stimulated the expression of DCD and the production of endogenous $\mathrm{H}_{2} \mathrm{~S}$ in roots, whereas blockade $\mathrm{H}_{2} \mathrm{~S}$ accumulation (back to normal levels) with PAG or HT led to the alleviation of $\mathrm{Cd}$-induced phytotoxicity. These results suggested that endogenously-generated $\mathrm{H}_{2} \mathrm{~S}$ mediated $\mathrm{Cd}$ toxicity in tobacco seedlings. It has been documented that $\mathrm{H}_{2} \mathrm{~S}$ promotes NADPH oxidase-dependent $\mathrm{H}_{2} \mathrm{O}_{2}$ production in Arabidopsis roots under salt stress [54]. Therefore, CA-blocked $\mathrm{H}_{2} \mathrm{~S}$ production may partially contribute to the inhibitory effect of $\mathrm{CA}_{\text {on }} \mathrm{H}_{2} \mathrm{O}_{2}$ accumulation in Cd-treated roots.

$\mathrm{H}_{2} \mathrm{~S}$ is a kind of "double-edged sword" during the disease responses in mammals. In addition to the protective role of $\mathrm{H}_{2} \mathrm{~S}$ against cell dysfunction [14], endogenous $\mathrm{H}_{2} \mathrm{~S}$ can also act as an important physiological mediator in inflammation of mammalian cells [55-57]. During the inflammation process, the expression of CSE is stimulated leading to the increase in $\mathrm{H}_{2} \mathrm{~S}$ biosynthesis. However, the inhibition of $\mathrm{H}_{2} \mathrm{~S}$ production with PAG shows anti-inflammatory activity [55-57]. These studies are similar to our current results that DCD-dependent $\mathrm{H}_{2} \mathrm{~S}$ formation contributed to $\mathrm{Cd}$-induced toxicity in tobacco roots. CA significantly repressed the expression of $D C D$ and the production of endogenous $\mathrm{H}_{2} \mathrm{~S}$ in $\mathrm{Cd}$-treated roots, leading to the alleviation of $\mathrm{Cd}$-induced phytotoxicity in tobacco seedlings. In addition, we found that the elevation of endogenous $\mathrm{H}_{2} \mathrm{~S}$ triggered cell death in Cd-treated roots, which could be blocked by CA. It has been suggested that $\mathrm{H}_{2} \mathrm{~S}$ induces caspase-dependent cell death in human cells [58,59]. Caspase-dependent cell death has been found in plants under Cd stress [60]. Thus, it is 
of interest to further investigate whether $\mathrm{CA}$ regulates caspase-dependent cell death by modulating endogenous $\mathrm{H}_{2} \mathrm{~S}$ in tobacco seedlings under $\mathrm{Cd}$ stress.

The meristem zone (MZ) in the root apex is vital for root elongation. MZ activity is regulated by a complex signaling network, involving ROS, abscisic acid, auxin, and cytokinin, etc. [61,62]. It has been reported that $\mathrm{Cd}$ inhibits root meristem growth by repressing NO-mediated auxin signaling in Arabidopsis [63]. ROS play important roles in the regulation of by regulating cell proliferation and differentiation $[62,64]$. Here we found that CA significantly suppressed ROS accumulation in the root apex under $\mathrm{Cd}$ exposure. Interestingly, CA is capable of modulating cell proliferation and differentiation in mammals [65]. Therefore, it is of interest to further investigate whether CA-suppressed ROS accumulation modulates apical meristem activity in the root tip of tobacco seedlings under $\mathrm{Cd}$ exposure.

As compared to the medical properties of CA, little information is known about the regulation of plant physiology by CA. Our current study proposes that CA is capable of conferring plant tolerance against $\mathrm{Cd}$ stress. CA significantly attenuates $\mathrm{Cd}$-inhibited root growth in tobacco seedlings by blocking Cd-induced oxidative injury and cell death. Generally, natural compounds tend to combat stress-induced oxidative injury by enhancing anti-oxidative capacity to remove over-generated ROS in mammalian cells [66]. However, our current study suggests that CA seems to inhibit the production of ROS, which is mediated by endogenous $\mathrm{H}_{2} \mathrm{~S}$ in tobacco seedlings under $\mathrm{Cd}$ exposure. The detailed mechanism for CA-facilitated plant adaption to $\mathrm{Cd}$ is still elusive, but our current results provide evidences for the regulation of plant-resistant physiology by CA. Therefore, CA would have great potential to be applied to help plants grow in heavy metal-polluted environments. Such findings could extend our knowledge of $\mathrm{CA}$ and $\mathrm{H}_{2} \mathrm{~S}$ in the regulation of plant physiology, which is vital for both fundamental and applied plant biology.

\section{Materials and Methods}

\subsection{Plant Culture, Treatment, and Chemicals}

Seeds of Nicotiana tabacum were germinated for $24 \mathrm{~h}$ in the dark on wet filter paper in a Petri dish at $25{ }^{\circ} \mathrm{C}$. Then 30 selected identical seedlings with $0.5 \mathrm{~cm}$ radicles were transferred to another wet filter paper in a new Petri dish. Then different treatment solutions $(5 \mathrm{~mL})$ were added into the Petri dish. Seedling roots were immersed into the treatment solution for different treatment times. Petri dishes with seedlings were put in a photosynthetic active radiation chamber of $200 \mu \mathrm{mol} / \mathrm{m}^{2} / \mathrm{s}$, a photoperiod of $12 \mathrm{~h}$, and a temperature of $25^{\circ} \mathrm{C}$. After treatment, the roots were harvested and washed with distilled water for histochemical, physiological, and biochemical analyses.

According to different experimental designs, the roots of seedlings were exposed to $\mathrm{CdCl}_{2}(20 \mu \mathrm{M})$, CA $(1-80 \mu \mathrm{M})$, NaHS $(20 \mu \mathrm{M})$, PAG $(2 \mu \mathrm{M})$, and HT $(20 \mu \mathrm{M})$, alone or in combined solutions for various treatment times $(0-72 \mathrm{~h})$. NaHS, PAG, and $\mathrm{HT}$ were applied as an $\mathrm{H}_{2} \mathrm{~S}$ donor, $\mathrm{H}_{2} \mathrm{~S}$ biosynthesis inhibitor, and $\mathrm{H}_{2} \mathrm{~S}$ scavenger, respectively [67]. All the chemicals used in this study were analytical reagents obtained from Sigma-Aldrich (St. Louis, MO, USA).

\subsection{Histochemical Analysis of Total ROS in Roots}

Intracellular total ROS in roots was visualized using specific fluorescent probe DCFH-DA in situ described by Foreman et al. [68]. The roots of seedlings were incubated in $10 \mu \mathrm{M}$ of DCFH-DA at $25^{\circ} \mathrm{C}$ for $10 \mathrm{~min}$. Then the roots were rinsed with distilled water three times, followed by visualization (excitation $488 \mathrm{~nm}$ and emission $525 \mathrm{~nm}$ ) with a fluorescence microscope (ECLIPSE, TE2000-S, Nikon, Melville, NY, USA). The relative fluorescent density of DCF was analyzed using Image-Pro Plus 6.0 (Media Cybernetics, Inc., Rockville, MD, USA). The roots without incubated with DCFH-DA were detected under the same conditions to exclude the possibility for the autofluorescence of root tissues. A similar procedure was also performed before using other fluorescent probes in this study. 


\subsection{Histochemical Detection of Intracellular $\mathrm{H}_{2} \mathrm{O}_{2}$ in Roots}

Intracellular $\mathrm{H}_{2} \mathrm{O}_{2}$ in roots was visualized in situ using specific fluorescent probe HPF described by Dunand and Crevecoeur [69]. The roots of seedlings after treatment were incubated in $5 \mu \mathrm{M}$ of $\mathrm{HPF}$ at $25{ }^{\circ} \mathrm{C}$ for $15 \mathrm{~min}$. Then the roots were rinsed with distilled water three times, followed by visualization (excitation $490 \mathrm{~nm}$ and emission $515 \mathrm{~nm}$ ) with a fluorescence microscope (ECLIPSE, TE2000-S, Nikon, Melville, NY, USA). The relative fluorescent density of HPF was analyzed using Image-Pro Plus 6.0 (Media Cybernetics, Inc., Rockville, MD, USA).

\subsection{Histochemical Detection of Intracellular $\mathrm{O}_{2}^{\bullet-}$ in Roots}

Intracellular $\mathrm{O}_{2}{ }^{\bullet-}$ in roots was visualized in situ using specific fluorescent probe DHE described by Yamamoto et al. [70]. The roots of seedlings after treatment were incubated in $15 \mu \mathrm{M}$ of DHE at $25^{\circ} \mathrm{C}$ for $15 \mathrm{~min}$. Then the roots were rinsed with distilled water three times, followed by visualization (excitation $535 \mathrm{~nm}$ and emission $610 \mathrm{~nm}$ ) with a fluorescence microscope (ECLIPSE, TE2000-S, Nikon, Melville, NY, USA). The relative fluorescent density of DHE was analyzed using Image-Pro Plus 6.0 (Media Cybernetics, Inc., Rockville, MD, USA).

\subsection{Histochemical Detection of Lipid Peroxidation in Roots}

Histochemical detection of lipid peroxidation was achieved by using Schiff's regent as described by Wang and Yang [71]. The roots of seedlings after treatment were incubated in Schiff's reagent for $20 \mathrm{~min}$. Then the stained roots were rinsed with a solution containing $0.5 \%(w / v) \mathrm{K}_{2} \mathrm{~S}_{2} \mathrm{O}_{5}$ (prepared in $0.05 \mathrm{M}$ of $\mathrm{HCl}$ ) until the root color became light red. After that, the roots were photographed by using a stereoscopic microscope (SteREO Discovery.V8, ZEISS, Oberkochen, Germany).

\subsection{Histochemical Detection of Loss of Membrane Integrity in Roots}

Histochemical detection of loss of plasma membrane integrity in roots was performed by using Evans blue as described by Yamamoto et al. [72]. The roots of seedlings after treatment were incubated in Evans blue solution $(0.025 \%, w / v)$ for $20 \mathrm{~min}$. After that, the roots were rinsed with distilled water three times, followed by imaging by using a stereoscopic microscope (SteREO Discovery.V8, ZEISS, Oberkochen, Germany).

\subsection{Determination of TBARS Content in Roots}

The concentration of TBARS was determined as an indicator of the level of lipid peroxidation in plants. A TBARS detection kit (A003; Nanjing Jiancheng Bioengineering Institute, Nanjing, China) was selected to measure the TBARS level based on the spectrophotometric determination of the reaction between TBARS and TBA (1,3-diethyl-2-thiobarbituric acid) assisted by TCA (trichloroacetic acid) [73].

\subsection{Histochemical Detection of Intracellular $\mathrm{H}_{2} \mathrm{~S}$ in Roots}

The intracellular $\mathrm{H}_{2} \mathrm{~S}$ in roots was visualized using specific fluorescent probe WSP-1 according to $\mathrm{Li}$ et al. [74] and Liu et al. [75]. The roots of seedlings after treatments were incubated at $20 \mathrm{mM}$ Hepes-NaOH ( $\mathrm{pH} 7.5$ ) buffer solution containing $20 \mu \mathrm{M}$ of WSP-1 at $25{ }^{\circ} \mathrm{C}$ for $40 \mathrm{~min}$. Then the roots were rinsed with distilled water three times, followed by visualization (excitation $465 \mathrm{~nm}$ and emission $515 \mathrm{~nm}$ ) with a fluorescence microscope (ECLIPSE, TE2000-S, Nikon, Melville, NY, USA). The relative fluorescent density of WSP-1 was analyzed using Image-Pro Plus 6.0 (Media Cybernetics, Inc., Rockville, MD, USA).

\subsection{Histochemical Detection of Cell Death in Roots}

Histochemical detection of cell death in roots was performed by using fluorescent probe PI (propidium iodide) in situ as described by Kellermeier et al. [76]. The roots of seedlings after treatment were incubated in $20 \mu \mathrm{M}$ of PI solution for $20 \mathrm{~min}$. Then the roots were rinsed with distilled water 
three times, followed by visualization (excitation $535 \mathrm{~nm}$ and emission $615 \mathrm{~nm}$ ) with a fluorescence microscope (ECLIPSE, TE2000-S, Nikon, Melville, NY, USA). The relative fluorescent density of PI was analyzed using Image-Pro Plus 6.0 (Media Cybernetics, Inc., Rockville, MD, USA).

\subsection{Histochemical Detection of Free $\mathrm{Cd}^{2+}$ in Roots}

Free $\mathrm{Cd}^{2+}$ in roots was detected in vivo by using fluorescent probe Leadmium ${ }^{\mathrm{TM}}$ Green AM [77]. The seedlings roots after treatment were harvested and washed in $1 \mathrm{mM}$ of EDTA for $3 \mathrm{~min}$, and rinsed with distilled water three times. Then the roots were incubated in $1 \mu \mathrm{g} / \mathrm{mL}$ of Leadmium ${ }^{\mathrm{TM}}$ Green $\mathrm{AM}$ at $25^{\circ} \mathrm{C}$ for $20 \mathrm{~min}$. Then the roots were rinsed with distilled water three times, followed by visualization (excitation $488 \mathrm{~nm}$ and emission $525 \mathrm{~nm}$ ) with a fluorescence microscope (ECLIPSE, TE2000-S, Nikon, Melville, NY, USA). The relative fluorescent density of Leadmium Green was analyzed using Image-Pro Plus 6.0 (Media Cybernetics, Inc., Rockville, MD, USA).

\subsection{Analysis of Gene Expression}

Real-time quantitative RT-PCR (reverse transcription-polymerase chain reaction) (qRT-PCR) was selected to quantify the expression levels of the genes. The sequences of LCD (XM_016597688.1) and DCD (XM_016611291.1) were obtained from NCBI (The National Center for Biotechnology Information) for the design of primers. Total RNA was extracted from roots using Trizol (Invitrogen) according to the manufacturer's instructions. Reverse transcription was performed at $42{ }^{\circ} \mathrm{C}$ in $25 \mu \mathrm{L}$ reaction mixture including $3 \mu \mathrm{g}$ of RNA, $0.5 \mu \mathrm{g}$ of oligo (dT) primers, $12.5 \mathrm{nmol}$ of dNTPs, 20 units of RANase inhibitor and 200 units of M-MLV. The first cDNA was used as a template for real-time RT-PCR analysis (Applied Biosystems 7500 Fast Real-Time PCR System, Applied Biosystems, Waltham, MA, USA) with SYBR Premix Ex Taq ${ }^{\mathrm{TM}}$ (TaKaRa Bio Inc., Dalian, China) according to the manufacturer's instructions. The qPCR procedure was as follows: initial denaturation at $95^{\circ} \mathrm{C}$ for $30 \mathrm{~s}$, followed by 40 cycles of $95{ }^{\circ} \mathrm{C}$ for $5 \mathrm{~s}, 60{ }^{\circ} \mathrm{C}$ for $30 \mathrm{~s}$, and $72{ }^{\circ} \mathrm{C}$ for $30 \mathrm{~s}$. Data were collected and analyzed by using ABI 7500 software (v. 2.0.6, Applied Biosystems) based on $2^{-\Delta \Delta C T}$ threshold cycle method [78]. The relative abundance of EF1- $\alpha$ (elongation factor 1- $\alpha$ ) was determined and used as the internal standard to normalize the data. The expression levels of corresponding genes are presented as values relative to the control samples under the indicated conditions. The primers used for amplifying the target genes are as follows: $L C D$, forward $5^{\prime}$-GGAGCCATGCTCTAGTGTTAAG- $3^{\prime}$ and reverse 5'-CCAATCCTACTCCAGTGTTTCC-3'; $D C D$, forward 5'-GGTGGCCTACTGGGTTTATATG- $3^{\prime}$ and reverse $5^{\prime}$-GCCGTCTTGTCTTGGGATAG- $3^{\prime}$; $E F 1-\alpha$, forward $5^{\prime}$-ATGATGACGACGATGATGATA- ${ }^{\prime}$ and reverse $5^{\prime}$-GTAAGCCCTTCTTGCTGAACAC-3').

\subsection{Cluster Analysis}

Hierarchical cluster analysis for different parameters was performed by using Cluster 3.0 (http://bonsai.hgc.jp/ mdehoon/software/cluster/) [79]. All the data of different treatments were transformed and presented as relative fold change $\left(\log _{2}\right)$ respect to their controls, respectively. The generated tree figure was displayed by using Java Treeview (https://sourceforge.net/projects/ jtreeview/) [80].

\subsection{Data Analysis}

Each result was presented as the mean \pm standard deviation (S.D.) of at least three replicated measurements. The significant differences between treatments were statistically evaluated by SD and one-way analysis of variance (ANOVA) using SPSS 14.0 (Statistical Package for the Social Science, SPSS Inc., Chicago, IL, USA). The data between two specific different treatments were compared statistically by ANOVA, followed by $F$-test if the ANOVA result is significant at $p<0.05$. For multiple comparison analysis, least significant difference test (LSD) was performed on all data following ANOVA tests to test for significant $(p<0.05)$ differences among different treatments. 
Acknowledgments: This work was support by the research fund from Chongqing Tobacco Corporation and Hongyun Honghe Tobacco Corporation (NY20140401070010) and Jiangsu Agriculture Science and Technology Innovation Fund (CX(14)2096).

Author Contributions: J.C. and X.-F.Y. conceived and designed the experiments; X.-F.Y., Y.X., T.L., and Y.W. performed the experiments; X.-F.Y., T.L., Y.X. and J.C. analyzed the data; X.-N.Y., C.C., G.F., L.H. and Z.S. contributed reagents/materials/analysis tools; X.-F.Y., Y.X., T.L., and J.C. wrote the paper.

Conflicts of Interest: The authors declare no conflict of interest.

\section{References}

1. Meena, V.; Sree, S.N.; Surya, P.D.V.; Sumanjali, A. A review on pharmacological activities and clinical effects of Cinnamon species. Res. J. Pharm. Biol. Chem. Sci. 2012, 3, 653-663.

2. Ranasinghe, P.; Pigera, S.; Premakumara, G.S.; Galappaththy, P.; Constantine, G.R.; Katulanda, P. Medicinal properties of 'true' cinnamon (Cinnamomum zeylanicum): A systematic review. BMC Complement. Altern. Med. 2013, 13, 275. [CrossRef] [PubMed]

3. Yang, D.; Liang, X.-c.; Shi, Y.; Sun, Q.; Liu, D.; Liu, W.; Zhang, H. Anti-oxidative and anti-inflammatory effects of cinnamaldehyde on protecting high glucose-induced damage in cultured dorsal root ganglion neurons of rats. Chin. J. Integr. Med. 2016, 22, 19-27. [CrossRef] [PubMed]

4. Roth-Walter, F.; Moskovskich, A.; Gomez-Casado, C.; Diaz-Perales, A.; Oida, K.; Singer, J.; Kinaciyan, T.; Fuchs, H.C.; Jensen-Jarolim, E. Immune suppressive effect of cinnamaldehyde due to inhibition of proliferation and induction of apoptosis in immune cells: Implications in cancer. PLoS ONE 2014, 9, e108402. [CrossRef] [PubMed]

5. Shreaz, S.; Wani, W.A.; Behbehani, J.M.; Raja, V.; Irshad, M.; Karched, M.; Ali, I.; Siddiqi, W.A.; Hun, L.T. Cinnamaldehyde and its derivatives, a novel class of antifungal agents. Fitoterapia 2016, 112, 116-131. [CrossRef] [PubMed]

6. Hayashi, K.; Imanishi, N.; Kashiwayama, Y.; Kawano, A.; Terasawa, K.; Shimada, Y.; Ochiai, H. Inhibitory effect of cinnamaldehyde, derived from Cinnamomi cortex, on the growth of influenza A/PR/8 virus in vitro and in vivo. Antivir. Res. 2007, 74, 1-8. [CrossRef] [PubMed]

7. Imai, T.; Yasuhara, K.; Tamura, T.; Takizawa, T.; Ueda, M.; Hirose, M.; Mitsumori, K. Inhibitory effects of cinnamaldehyde on 4-(methylnitrosamino)-1-(3-pyridyl)-1-butanone-induced lung carcinogenesis in rasH2 mice. Cancer Lett. 2002, 175, 9-16. [CrossRef]

8. Raffai, G.; Kim, B.; Park, S.; Khang, G.; Lee, D.; Vanhoutte, P.M. Cinnamaldehyde and cinnamaldehyde-containing micelles induce relaxation of isolated porcine coronary arteries: Role of nitric oxide and calcium. Int. J. Nanomedicine 2014, 9, 2557-2566. [CrossRef] [PubMed]

9. Huang, J.S.; Lee, Y.H.; Chuang, L.Y.; Guh, J.Y.; Hwang, J.Y. Cinnamaldehyde and nitric oxide attenuate advanced glycation end products-induced the Jak/STAT signaling in human renal tubular cells. J. Cell. Biochem. 2015, 116, 1028-1038. [CrossRef] [PubMed]

10. Burt, S. Essential oils: Their antibacterial properties and potential applications in foods-A review. Int. J. Food Microbiol. 2004, 94, 223-253. [CrossRef] [PubMed]

11. Satarug, S.; Garrett, S.H.; Sens, M.A.; Sens, D.A. Cadmium, environmental exposure, and health outcomes. Environ. Health Perspect. 2010, 118, 182-190. [CrossRef] [PubMed]

12. Das, P.; Samantaray, S.; Rout, G.R. Studies on cadmium toxicity in plants: A review. Environ. Pollut. 1997, 98, 29-36. [CrossRef]

13. Chmielowska-Bakk, J.; Gzyl, J.; Rucińska-Sobkowiak, R.; Arasimowicz-Jelonek, M.; Deckert, J. The new insights into cadmium sensing. Front. Plant Sci. 2014, 5, 245. [CrossRef] [PubMed]

14. Li, L.; Rose, P.; Moore, P.K. Hydrogen sulfide and cell signaling. Annu. Rev. Pharmacol. Toxicol. 2011, 51, 169-187. [CrossRef] [PubMed]

15. Lisjak, M.; Teklic, T.; Wilson, I.D.; Whiteman, M.; Hancock, J.T. Hydrogen sulfide: Environmental factor or signalling molecule? Plant Cell Environ. 2013, 36, 1607-1616. [CrossRef] [PubMed]

16. Hancock, J.T.; Whiteman, M. Hydrogen sulfide signaling: Interactions with nitric oxide and reactive oxygen species. Ann. N. Y. Acad. Sci. 2016, 1365, 5-14. [CrossRef] [PubMed]

17. Munaron, L.; Avanzato, D.; Moccia, F.; Mancardi, D. Hydrogen sulfide as a regulator of calcium channels. Cell Calcium 2013, 53, 77-84. [CrossRef] [PubMed] 
18. Wang, R. Hydrogen sulfide: The third gasotransmitter in biology and medicine. Antioxid. Redox Signal. 2010, 12, 1061-1064. [CrossRef] [PubMed]

19. Jin, Z.; Pei, Y. Physiological implications of hydrogen sulfide in plants: Pleasant exploration behind its unpleasant odour. Oxid. Med. Cell. Longev. 2015, 2015, 397502. [CrossRef] [PubMed]

20. Papenbrock, J.; Riemenschneider, A.; Kamp, A.; Schulz-Vogt, H.N.; Schmidt, A. Characterization of cysteine-degrading and $\mathrm{H}_{2}$ S-releasing enzymes of higher plants - from the field to the test tube and back. Plant Biol. 2007, 9, 582-588. [CrossRef] [PubMed]

21. Fotopoulos, V.; Christou, A.; Antoniou, C.; Manganaris, G.A. Hydrogen sulphide: A versatile tool for the regulation of growth and defence responses in horticultural crops. J. Hortic. Sci. Biotechnol. 2015, 90, 227-234. [CrossRef]

22. Li, L.; Wang, Y.; Shen, W. Roles of hydrogen sulfide and nitric oxide in the alleviation of cadmium-induced oxidative damage in alfalfa seedling roots. Biometals 2012, 25, 617-631. [CrossRef] [PubMed]

23. Sun, J.; Wang, R.; Zhang, X.; Yu, Y.; Zhao, R.; Li, Z.; Chen, S. Hydrogen sulfide alleviates cadmium toxicity through regulations of cadmium transport across the plasma and vacuolar membranes in Populus euphratica cells. Plant Physiol. Biochem. 2013, 65, 67-74. [CrossRef] [PubMed]

24. Zhang, L.; Pei, Y.; Wang, H.; Jin, Z.; Liu, Z.; Qiao, Z.; Fang, H.; Zhang, Y. Hydrogen sulfide alleviates cadmium-induced cell death through restraining ROS accumulation in roots of Brassica rapa L. ssp. pekinensis. Oxid. Med. Cell. Longev. 2015, 2015, 804603. [PubMed]

25. Cui, W.; Chen, H.; Zhu, K.; Jin, Q.; Xie, Y.; Cui, J.; Xia, Y.; Zhang, J.; Shen, W. Cadmium-induced hydrogen sulfide synthesis is involved in cadmium tolerance in Medicago sativa by reestablishment of reduced (Homo)glutathione and reactive oxygen species homeostases. PLoS ONE 2014, 9, e109669. [CrossRef] [PubMed]

26. Shi, H.; Ye, T.; Chan, Z. Nitric oxide-activated hydrogen sulfide is essential for cadmium stress response in bermudagrass (Cynodon dactylon (L). Pers.). Plant Physiol. Biochem. 2014, 74, 99-107. [CrossRef] [PubMed]

27. Qiao, Z.; Jing, T.; Jin, Z.; Liang, Y.; Zhang, L.; Liu, Z.; Liu, D.; Pei, Y. CDPKs enhance Cd tolerance through intensifying $\mathrm{H}_{2} \mathrm{~S}$ signal in Arabidopsis thaliana. Plant Soil 2016, 398, 99-110. [CrossRef]

28. Mostofa, M.G.; Rahman, A.; Ansary, M.M.U.; Watanabe, A.; Fujita, M.; Tran, L.-S.P. Hydrogen sulfide modulates cadmium-induced physiological and biochemical responses to alleviate cadmium toxicity in rice. Sci. Rep. 2015, 5, 14078. [CrossRef] [PubMed]

29. Fang, H.; Jing, T.; Liu, Z.; Zhang, L.; Jin, Z.; Pei, Y. Hydrogen sulfide interacts with calcium signaling to enhance the chromium tolerance in Setaria italica. Cell Calcium 2014, 56, 472-481. [CrossRef] [PubMed]

30. Shahid, M.; Pourrut, B.; Dumat, C.; NADEEM, M.; Aslam, M.; Pinelli, E. Heavy-metal-induced reactive oxygen species: Phytotoxicity and physicochemical changes in plants. In Reviews of Environmental Contamination and Toxicology; Whitacre, D.M., Ed.; Springer International Publishing: Cham, Switzerland, 2014; Volume 232, pp. 1-44.

31. Gill, S.S.; Tuteja, N. Reactive oxygen species and antioxidant machinery in abiotic stress tolerance in crop plants. Plant Physiol. Biochem. 2010, 48, 909-930. [CrossRef] [PubMed]

32. Molania, T.; Moghadamnia, A.A.; Pouramir, M.; Aghel, S.; Moslemi, D.; Ghassemi, L.; Motallebnejad, M. The effect of Cinnamaldehyde on mucositis and salivary antioxidant capacity in gamma-irradiated rats (a preliminary study). DARU J. Pharm. Sci. 2012, 20, 89. [CrossRef] [PubMed]

33. Chao, L.K.; Chang, W.T.; Shih, Y.W.; Huang, J.S. Cinnamaldehyde impairs high glucose-induced hypertrophy in renal interstitial fibroblasts. Toxicol. Appl. Pharmacol. 2010, 244, 174-180. [CrossRef] [PubMed]

34. Di Marco, G.; Gismondi, A.; Canuti, L.; Scimeca, M.; Volpe, A.; Canini, A. Tetracycline accumulates in Iberis sempervirens L. through apoplastic transport inducing oxidative stress and growth inhibition. Plant Biol. 2014, 16, 792-800. [CrossRef] [PubMed]

35. Wang, W. Root elongation method for toxicity testing of organic and inorganic pollutants. Environ. Toxicol. Chem. 1987, 6, 409-414. [CrossRef]

36. Kahle, H. Response of roots of trees to heavy metals. Environ. Exp. Bot. 1993, 33, 99-119. [CrossRef]

37. Cloyd, R.A.; Cycholl, N.L. Phytotoxicity of selected insecticides on greenhouse-grown herbs. Hortscience 2002, 37, 671-672.

38. Subash-Babu, P.; Alshatwi, A.A.; Ignacimuthu, S. Beneficial antioxidative and antiperoxidative effect of cinnamaldehyde protect streptozotocin-induced pancreatic $\beta$-cells damage in wistar rats. Biomol. Ther. 2014, 22, 47-54. [CrossRef] [PubMed] 
39. Garnier, L.; Simon-Plas, F.; Thuleau, P.; Agnel, J.-P.; Blein, J.-P.; Ranjeva, R.; Montillet, J.-L. Cadmium affects tobacco cells by a series of three waves of reactive oxygen species that contribute to cytotoxicity. Plant Cell Environ. 2006, 29, 1956-1969. [CrossRef] [PubMed]

40. Cho, U.-H.; Seo, N.-H. Oxidative stress in Arabidopsis thaliana exposed to cadmium is due to hydrogen peroxide accumulation. Plant Sci. 2005, 168, 113-120. [CrossRef]

41. Van Breusegem, F.; Dat, J.F. Reactive oxygen species in plant cell death. Plant Physiol. 2006, 141, $384-390$. [CrossRef] [PubMed]

42. Montillet, J.L.; Chamnongpol, S.; Rusterucci, C.; Dat, J.; van de Cotte, B.; Agnel, J.P.; Battesti, C.; Inze, D.; Van Breusegem, F.; Triantaphylides, C. Fatty acid hydroperoxides and $\mathrm{H}_{2} \mathrm{O}_{2}$ in the execution of hypersensitive cell death in tobacco leaves. Plant Physiol. 2005, 138, 1516-1526. [CrossRef] [PubMed]

43. Heath, R.L.; Packer, L. Photoperoxidation in isolated chloroplasts. I. Kinetics and stoichiometry of fatty acid peroxidation. Arch. Biochem. Biophys. 1968, 125, 189-198. [CrossRef]

44. Suzuki, N.; Miller, G.; Morales, J.; Shulaev, V.; Torres, M.A.; Mittler, R. Respiratory burst oxidases: The engines of ROS signaling. Curr. Opin. Plant Biol. 2011, 14, 691-699. [CrossRef] [PubMed]

45. Wen, J.; Deng, M.; Gong, M. Cd ${ }^{2+}$ stress induces two waves of $\mathrm{H}_{2} \mathrm{O}_{2}$ accumulation associated with ROS-generating system and ROS-scavenging system in cultured tobacco cells. Aust. J. Crop Sci. 2012, 6, 846-853.

46. Kang, L.-L.; Zhang, D.-M.; Ma, C.-H.; Zhang, J.-H.; Jia, K.-K.; Liu, J.-H.; Wang, R.; Kong, L.-D. Cinnamaldehyde and allopurinol reduce fructose-induced cardiac inflammation and fibrosis by attenuating CD36-mediated TLR4/6-IRAK4/1 signaling to suppress NLRP3 inflammasome activation. Sci. Rep. 2016, 6, 27460. [CrossRef] [PubMed]

47. Chao, L.K.; Hua, K.-F.; Hsu, H.-Y.; Cheng, S.-S.; Lin, I.F.; Chen, C.-J.; Chen, S.-T.; Chang, S.-T. Cinnamaldehyde inhibits pro-inflammatory cytokines secretion from monocytes/macrophages through suppression of intracellular signaling. Food Chem. Toxicol. 2008, 46, 220-231. [CrossRef] [PubMed]

48. Wang, F.; Pu, C.; Zhou, P.; Wang, P.; Liang, D.; Wang, Q.; Hu, Y.; Li, B.; Hao, X. Cinnamaldehyde prevents endothelial dysfunction induced by high glucose by activating Nrf2. Cell. Physiol. Biochem. 2015, 36, 315-324. [CrossRef] [PubMed]

49. Mendes, S.J.F.; Sousa, F.I.A.B.; Pereira, D.M.S.; Ferro, T.A.F.; Pereira, I.C.P.; Silva, B.L.R.; Pinheiro, A.J.M.C.R.; Mouchrek, A.Q.S.; Monteiro-Neto, V.; Costa, S.K.P.; et al. Cinnamaldehyde modulates LPS-induced systemic inflammatory response syndrome through TRPA1-dependent and independent mechanisms. Int. Immunopharmacol. 2016, 34, 60-70. [CrossRef] [PubMed]

50. Pannee, C.; Chandhanee, I.; Wacharee, L. Antiinflammatory effects of essential oil from the leaves of Cinnamomum cassia and cinnamaldehyde on lipopolysaccharide-stimulated J774A.1 cells. J. Adv. Pharm. Tech. Res. 2014, 5, 164-170. [CrossRef] [PubMed]

51. Del Carlo, M., Jr.; Loeser, R.F. Nitric oxide-mediated chondrocyte cell death requires the generation of additional reactive oxygen species. Arthritis. Rheum. 2002, 46, 394-403. [CrossRef] [PubMed]

52. Zago, E.; Morsa, S.; Dat, J.F.; Alard, P.; Ferrarini, A.; Inze, D.; Delledonne, M.; Van Breusegem, F. Nitric oxide- and hydrogen peroxide-responsive gene regulation during cell death induction in tobacco. Plant Physiol. 2006, 141, 404-411. [CrossRef] [PubMed]

53. De Michele, R.; Vurro, E.; Rigo, C.; Costa, A.; Elviri, L.; Di Valentin, M.; Careri, M.; Zottini, M.; Sanita di Toppi, L.; Lo Schiavo, F. Nitric oxide is involved in cadmium-induced programmed cell death in Arabidopsis suspension cultures. Plant Physiol. 2009, 150, 217-228. [CrossRef] [PubMed]

54. Li, J.; Jia, H.; Wang, J.; Cao, Q.; Wen, Z. Hydrogen sulfide is involved in maintaining ion homeostasis via regulating plasma membrane $\mathrm{Na}^{+} / \mathrm{H}^{+}$antiporter system in the hydrogen peroxide-dependent manner in salt-stress Arabidopsis thaliana root. Protoplasma 2014, 251, 899-912. [CrossRef] [PubMed]

55. Bhatia, M.; Sidhapuriwala, J.; Moochhala, S.M.; Moore, P.K. Hydrogen sulphide is a mediator of carrageenan-induced hindpaw oedema in the rat. Br. J. Pharmacol. 2005, 145, 141-144. [CrossRef] [PubMed]

56. Tamizhselvi, R.; Moore, P.K.; Bhatia, M. Hydrogen sulfide acts as a mediator of inflammation inacute pancreatitis: In vitro studies using isolated mouse pancreatic acinar cells. J. Cell. Mol. Med. 2007, 11, 315-326. [CrossRef] [PubMed]

57. Li, L.; Bhatia, M.; Zhu, Y.Z.; Zhu, Y.C.; Ramnath, R.D.; Wang, Z.J.; Anuar, F.B.M.; Whiteman, M.; Salto-Tellez, M.; Moore, P.K. Hydrogen sulfide is a novel mediator of lipopolysaccharide-induced inflammation in the mouse. FASEB J. 2005, 19, 1196-1198. [CrossRef] [PubMed] 
58. Kobayashi, C.; Yaegaki, K.; Calenic, B.; Ishkitiev, N.; Imai, T.; Ii, H.; Aoyama, I.; Kobayashi, H.; Izumi, Y.; Haapasalo, M. Hydrogen sulfide causes apoptosis in human pulp stem cells. J. Endod. 2011, 37, 479-484. [CrossRef] [PubMed]

59. Zhang, J.H.; Dong, Z.; Chu, L. Hydrogen sulfide induces apoptosis in human periodontium cells. J. Periodontal Res. 2010, 45, 71-78. [CrossRef] [PubMed]

60. Ye, Y.U.N.; Li, Z.H.E.; Xing, D.A. Nitric oxide promotes MPK6-mediated caspase-3-like activation in cadmium-induced Arabidopsis thaliana programmed cell death. Plant Cell Environ. 2013, 36, 1-15. [CrossRef] [PubMed]

61. Perilli, S.; Di Mambro, R.; Sabatini, S. Growth and development of the root apical meristem. Curr. Opin. Plant Biol. 2012, 15, 17-23. [CrossRef] [PubMed]

62. Yang, L.; Zhang, J.; He, J.; Qin, Y.; Hua, D.; Duan, Y.; Chen, Z.; Gong, Z. ABA-mediated ROS in mitochondria regulate root meristem activity by controlling PLETHORA expression in Arabidopsis. PLoS Genet. 2014, 10, e1004791. [CrossRef] [PubMed]

63. Yuan, H.-M.; Huang, X. Inhibition of root meristem growth by cadmium involves nitric oxide-mediated repression of auxin accumulation and signalling in Arabidopsis. Plant Cell Environ. 2016, 39, 120-135. [CrossRef] [PubMed]

64. Tsukagoshi, H.; Busch, W.; Benfey, P.N. Transcriptional regulation of ROS controls transition from proliferation to differentiation in the root. Cell 2010, 143, 606-616. [CrossRef] [PubMed]

65. Koh, W.S.; Yoon, S.Y.; Kwon, B.M.; Jeong, T.C.; Nam, K.S.; Han, M.Y. Cinnamaldehyde inhibits lymphocyte proliferation and modulates T-cell differentiation. Int J. Immunopharmacol. 1998, 20, 643-660. [CrossRef]

66. Raut, J.S.; Karuppayil, S.M. A status review on the medicinal properties of essential oils. Ind. Crops Prod. 2014, 62, 250-264. [CrossRef]

67. Chen, Y.; Mo, H.Z.; Zheng, M.Y.; Xian, M.; Qi, Z.Q.; Li, Y.Q.; Hu, L.B.; Chen, J.; Yang, L.F. Selenium inhibits root elongation by repressing the generation of endogenous hydrogen sulfide in Brassica rapa. PLoS ONE 2014, 9, e110904. [CrossRef] [PubMed]

68. Foreman, J.; Demidchik, V.; Bothwell, J.H.; Mylona, P.; Miedema, H.; Torres, M.A.; Linstead, P.; Costa, S.; Brownlee, C.; Jones, J.D.; et al. Reactive oxygen species produced by NADPH oxidase regulate plant cell growth. Nature 2003, 422, 442-446. [CrossRef] [PubMed]

69. Dunand, C.; Crèvecoeur, M.; Penel, C. Distribution of superoxide and hydrogen peroxide in Arabidopsis root and their influence on root development: Possible interaction with peroxidases. New Phytol. 2007, 174, 332-341. [CrossRef] [PubMed]

70. Yamamoto, Y.; Kobayashi, Y.; Devi, S.R.; Rikiishi, S.; Matsumoto, H. Aluminum toxicity is associated with mitochondrial dysfunction and the production of reactive oxygen species in plant cells. Plant Physiol. 2002, 128, 63-72. [CrossRef] [PubMed]

71. Wang, Y.S.; Yang, Z.M. Nitric oxide reduces aluminum toxicity by preventing oxidative stress in the roots of Cassia tora L. Plant Cell Physiol. 2005, 46, 1915-1923. [CrossRef] [PubMed]

72. Yamamoto, Y.; Kobayashi, Y.; Matsumoto, H. Lipid peroxidation is an early symptom triggered by aluminum, but not the primary cause of elongation inhibition in pea roots. Plant Physiol. 2001, 125, 199-208. [CrossRef] [PubMed]

73. Yang, Y.; Fan, F.; Zhuo, R.; Ma, F.; Gong, Y.; Wan, X.; Jiang, M.; Zhang, X. Expression of the laccase gene from a white rot fungus in Pichia pastoris can enhance the resistance of this yeast to $\mathrm{H}_{2} \mathrm{O}_{2}$-mediated oxidative stress by stimulating the glutathione-based antioxidative system. Appl. Environ. Microbiol. 2012, 78, 5845-5854. [CrossRef] [PubMed]

74. Li, Y.J.; Chen, J.; Xian, M.; Zhou, L.G.; Han, F.X.; Gan, L.J.; Shi, Z.Q. In site bioimaging of hydrogen sulfide uncovers its pivotal role in regulating nitric oxide-induced lateral root formation. PLoS ONE 2014, 9, e90340. [CrossRef] [PubMed]

75. Liu, C.; Pan, J.; Li, S.; Zhao, Y.; Wu, L.Y.; Berkman, C.E.; Whorton, A.R.; Xian, M. Capture and visualization of hydrogen sulfide by a fluorescent probe. Angewandte Chemie 2011, 123, 10511-10513. [CrossRef]

76. Kellermeier, F.; Chardon, F.; Amtmann, A. Natural variation of Arabidopsis root architecture reveals complementing adaptive strategies to potassium starvation. Plant Physiol. 2013, 161, 1421-1432. [CrossRef] [PubMed] 
77. Brunetti, P.; Zanella, L.; De Paolis, A.; Di Litta, D.; Cecchetti, V.; Falasca, G.; Barbieri, M.; Altamura, M.M.; Costantino, P.; Cardarelli, M. Cadmium-inducible expression of the ABC-type transporter AtABCC3 increases phytochelatin-mediated cadmium tolerance in Arabidopsis. J. Exp. Bot. 2015, 66, 3815-3829. [CrossRef] [PubMed]

78. Livak, K.J.; Schmittgen, T.D. Analysis of relative gene expression data using Real-Time Quantitative PCR and the $2^{-\triangle \triangle C T}$ method. Methods 2001, 25, 402-408. [CrossRef] [PubMed]

79. Eisen, M. Cluster 3.0. Available online: http://bonsai.hgc.jp/ mdehoon/software/cluster/ (accessed on 23 December 2016).

80. Saldanha, A.J. Java Treeview-extensible visualization of microarray data. Bioinformatics 2004, 20, 3246-3248. [CrossRef] [PubMed]

Sample Availability: Samples of the compounds are available from the authors

(C) 2016 by the authors; licensee MDPI, Basel, Switzerland. This article is an open access article distributed under the terms and conditions of the Creative Commons Attribution (CC-BY) license (http://creativecommons.org/licenses/by/4.0/). 